\title{
Pengembangan Bahan Ajar Geometri SMP Berbasis Cognitive Load Theory Berorientasi pada Prestasi Belajar Siswa
}

\author{
Fitraning Tyas Puji Pangesti ${ }^{1} *$ Endah Retnowati $^{1}$ \\ ${ }^{1}$ Program Studi Pendidikan Matematika, Program Pascasarjana, Universitas Negeri Yogyakarta. \\ Jalan Colombo No. 1, Karangmalang, Yogyakarta 55281, Indonesia \\ * Corresponding Author. email: fitraningtyas@yahoo.co.id, Telp: +62274-550836 \\ Received: 20 May 2017; Revised:7 June 2017; Accepted: 10 June 2017
}

\begin{abstract}
Abstrak
Penelitian ini bertujuan untuk menghasilkan bahan ajar geometri SMP berbasis Cognitive Load Theory (CLT) serta mendeskripsikan kualitas kevalidan, kepraktisan dan keefektifan bahan ajar tersebut. Bahan ajar yang dikembangkan berupa buku pengayaan geometri untuk SMP kelas VII dan VIII sesuai dengan Kurikulum 2006. Jenis penelitian ini adalah penelitian kualitatif dengan menggunakan model penelitian desain dari Plomp yang terdiri atas tiga tahap: preliminary research, prototyping phase, dan assessment phase. Subjek coba terdiri atas 32 siswa kelas VII dan 32 siswa kelas VIII dari dua SMP Negeri di Kabupaten Wonosobo, beserta masing-masing satu guru matematika dari sekolah tersebut. Subjek coba yang menggunakan bahan ajar ini telah menguasai kompetensi dasar pembelajaran. Penelitian ini menghasilkan bahan ajar geometri SMP berbasis CLT yang memenuhi aspek kevalidan, kepraktisan dan keefektifan. Hasil evaluasi formatif 1 menyatakan bahwa bahan ajar yang dikembangkan memenuhi kriteria valid. Hasil evaluasi formatif 2 dan evaluasi sumatif menyatakan bahwa bahan ajar memenuhi kriteria praktis. Keefektifan bahan ajar terlihat dari hasil penilaian prestasi belajar yang menunjukkan bahwa persentase siswa kelas VII yang mencapai KKM adalah $78 \%$ dengan rata-rata nilai klasikal 78 dan persentase siswa kelas VIII yang mencapai KKM adalah $75 \%$ dengan rata-rata nilai klasikal 80 . Secara keseluruhan, hasil penelitian menunjukkan bahwa bahan ajar yang dikembangkan layak digunakan.
\end{abstract}

Kata Kunci: bahan ajar, pengayaan, geometri SMP, cognitive load theory

\section{Developing Geometry Learning Materials for Junior High School Based on Cognitive Load Theory With Regard to Student's Achievement}

\begin{abstract}
This study was aimed to develop a geometry learning materials for junior high school based on Cognitive Load Theory $(C L T)$ and to describe the quality with respect to the validity, practicality, and effectiveness of the developed learning materials consisting of advanced geometry for seventh and eighth graders referring to the Curriculum of 2006. The research was a qualitative study using design research model suggested by Plomp, involving three phases: preliminary research, prototyping, and assessment. Research participants were 32 seventh and 32 eighth grade students at two public junior high schools in Wonosobo, as well as their mathematics teachers. These students had acquired minimum competencies to use the learning materials. This research resulted in junior high school geometry learning materials based on CLT, which satisfies the validity, practicality, and effectiveness aspects. The result of first formative evaluation informed that learning materials were categorized valid. The results of second formative evaluation and summative evaluation revealed that the learning materials were categorized practical. The effectiveness of learning materials could be seen from the results of the achievement test which showed that the percentage of seventh graders who passed the minimum criteria was 78\%, with an average test score was 78; and the percentage of eighth graders who passed the minimum criteria was $75 \%$, with an average test score was 80 . Overall, the results showed that the developed learning materials can be used widely.
\end{abstract}

Keywords: learning materials, advance, geometry SMP, cognitive load theory

How to Cite: Pangesti, F., \& Retnowati, E. (2017). Pengembangan bahan ajar geometri SMP berbasis cognitive load theory berorientasi pada prestasi belajar siswa. PYTHAGORAS: Jurnal Pendidikan Matematika, 12(1), 33 46. doi:http://dx.doi.org/10.21831/pg.v12i1.14055

Permalink/DOI: http://dx.doi.org/10.21831/pg.v12i1.14055 
Pythagoras, 12 (1), 2017 - 34

Fitraning Tyas Puji Pangesti, Endah Retnowati

\section{PENDAHULUAN}

Geometri dipandang sebagai salah satu bagian matematika yang penting untuk dipelajari. Menurut NCTM (2007, p.72), ada tiga alasan yang mendukung pendapat tersebut. Pertama, bentuk-bentuk geometri banyak yang mendasarkan pada benda-benda di dunia nyata, contohnya sarang lebah, balok kayu, serta dadu. Kedua, banyak permasalahan matematika dapat divisualisasikan dengan geometri, misalnya data statistika dapat digambarkan dalam berbagai bentuk diagram sehingga lebih mudah dipahami. Ketiga, secara umum geometri merupakan sistem ilmu terstruktur yang terdiri atas aksioma, definisi, dan teorema sehingga dengan keteraturan tersebut memungkinkan matematikawan melakukan pengembangan kemampuan berfikir logis dan sistematis. Groth (2013, p.337) menyatakan bahwa tujuan dasar mempelajari geometri yaitu: memperoleh pemahaman, mampu mendefinisikan bentuk-bentuk geometri, dan mengkonstruksikan bukti.

Salah satu cara yang dapat dilakukan guru untuk mengembangkan kompetensi geometri siswa yaitu dengan memberikan materi pengayaan terutama bagi siswa yang telah menguasai kompetensi dasar minimal dan alokasi waktu pembelajaran mencukupi. Sekolah perlu memfasilitasi siswa-siswa tersebut dengan program pembelajaran pengayaan yaitu pembelajaran tambahan bagi siswa untuk memaksimalkan perkembangan minat, keterampilan berpikir dan memecahkan masalah, serta kreativitas dalam matematika. Pembelajaran pengayaan ini memberikan "...tantangan belajar yang lebih tinggi untuk membantu mereka mencapai kapasitas optimal dalam belajarnya." (Direktorat Pembinaan SMA, 2008b, p.3).

Terdapat beberapa faktor penyebab pembelajaran geometri siswa SMP di Indonesia belum optimal, antara lain: (1) siswa masih menganggap bahwa geometri merupakan pelajaran yang sulit (Wahyuni \& Rudhito, 2012, pp.M1-2); (2) metode pembelajaran kurang sesuai dengan karakteristik materi geometri yang dipelajari siswa (Safrina, Ikhsan, \& Ahmad, 2014, p.9); (3) terbatasnya alat peraga dan bahan ajar geometri berkualitas (Bastiani \& Rudhito, 2012, pp.M101-108); (4) kurang tersedianya bahan ajar pengayaan yang layak digunakan (Sitepu, 2014, p.52); dan (5) siswa cenderung menghafal rumus geometri namun tidak memahami cara untuk menerapkannya (Sarjiman, 2006, p.75).
Bahan ajar sebaiknya tidak hanya berisi uraian materi namun juga harus disertai dengan instruksi yang mendorong siswa untuk memahami konsep geometri dalam penyelesaian masalah. Terbatasnya bahan ajar berkualitas diduga menjadi faktor utama penyebab kesulitan belajar geometri, khususnya bahan ajar yang berisi materi-materi pengayaan. Hal ini didukung oleh penelitian Wijaya, VandenHeuvelPanhuizen, \& Doorman (2015, p.41) tentang kualitas bahan ajar berupa buku-buku teks matematika di Indonesia. Simpulan yang diperoleh dari penelitian tersebut adalah buku teks matematika yang digunakan kurang berkualitas sehingga menyebabkan kesulitan siswa dalam penyelesaian soal.

Dalam buku Panduan Pengembangan Bahan Ajar yang diterbitkan oleh Depdiknas disebutkan bahwa "bahan ajar adalah segala bentuk bahan yang digunakan untuk membantu guru/instruktor dalam melaksanakan kegiatan belajar mengajar" (Direktorat Pembinaan SMA, 2008a, p.6). Bahan ajar berperan dalam mengembangkan kemampuan intelektual, keterampilan, serta prestasi belajar siswa. Oleh karena itu sangat penting bagi guru untuk menyusun bahan ajar yang berkualitas untuk mengefektifkan kegiatan pembelajarannya. Nwike dan Cathrine (2013, p.103) telah menyatakan "to achieve effective teaching and learning process, there is the need for use instructional materials." Sependapat dengan Oladejo, Olosunde, Ojebisi, dan Isola (2011, p.113) yang menyebutkan pemanfaatan bahan ajar berpotensi meningkatkan keefektifan pembelajaran. Lebih lanjut dijelaskan bahwa kecakapan guru dalam menyusun materi-materi pembelajaran membuat kegiatan pembelajaran menjadi lebih efektif sekaligus berdampak pada meningkatkan prestasi belajar siswa.

Untuk menyusun bahan ajar, guru perlu memperhatikan bagaimana sistem kognitif siswa bekerja pada saat belajar. Retnowati (2008) mengemukakan belajar merupakan proses mengubah susunan pengetahuan dari pengetahuan yang telah dimiliki sebelumnya dan tersimpan dalam otak melalui rekonstruksi pengetahuan lama atau dengan menambahkan pengetahuan baru. Belajar dalam pengertian ini didasarkan pada bagaimana sistem kognitif bekerja untuk memahami pengetahuan secara bermakna, oleh karena itu Retnowati (2008, p.8) menyarankan pentingnya memahami cara kerja sistem kognitif ketika mengkonstruksi pengetahuan dan menyajikan bahan ajar. 
Pythagoras, 12 (1), 2017 - 35

Fitraning Tyas Puji Pangesti, Endah Retnowati

Pengetahuan tentang bagaimana manusia belajar, berpikir, dan memecahkan masalah berhubungan dengan arsitektur kognitif manusia. Sweller menyebutkan "Cognitive Load Theory (CLT) began as an instructional theory based on our knowledge of human cognitive architecture" (Sweller, 2010a, p.29). Arsitektur kognitif ini mengacu pada struktur memori manusia yang terdiri atas memori penginderaan, memori pekerja, dan memori jangka panjang dalam usaha untuk mengolah dan menyimpan informasi (Retnowati, 2008, p.1, Sweller, Ayres, \& Kalyuga, 2011, p.15).

Informasi yang baru pertama kali diterima harus diolah dalam memori pekerja. Memori ini memiliki keterbatasan kapasitas maupun durasi sehingga ketika mengolah sejumlah besar informasi baru dalam waktu yang bersamaan dapat berpotensi menimbulkan suatu muatan kognitif. Sweller menyatakan terdapat dua sumber muatan kognitif yang mempengaruhi memori pekerja yaitu intrinsic cognitive load dan extraneous cognitive load, sedangkan germane cognitive load adalah muatan kognitif yang muncul karena kapasitas memori pekerja untuk mengatur intrinsic dan extraneous cognitive load (Sweller, 2010a, pp.41-44; Sweller, et al., 2011, p.57).

Intrinsic cognitive load ditentukan oleh tingkat kompleksitas informasi atau materi yang sedang dipelajari. Beberapa materi secara intrinsik sulit untuk dipahami dan akhirnya diberikan tanpa memperhatikan bagaimana seharusnya materi tersebut diajarkan. Faktor penting dalam mengajarkan suatu materi yaitu memahami timbulnya elemen interaktivitas, yakni sejumlah elemen yang secara bersamasama harus diproses dalam memori pekerja di bawah instruksi (Sweller, 2010b, p.124) contohnya, konsep maupun prosedur penyelesaian soal matematika.

Elemen interaktivitas yang tinggi menyebabkan intrinsic cognitive load menjadi tinggi. Dalam beberapa hal, unsur interaktivitas bersifat tetap karena secara intrinsik dimiliki oleh semua materi yang harus dipelajari dan tidak dapat diubah, misalnya pada materi kesebangunan segitiga, sebagian besar siswa kesulitan untuk membayangkan dan menunjukkan bukti kesebangunan dua segitiga (Yohanes, Subanji, \& Sisworo, 2016, p.187). Meskipun demikian, siswa tetap mempelajari konsep dan aplikasi kesebangunan segitiga karena materi tersebut tercantum dalam Kurikulum 2006 sebagai salah satu KD geometri di kelas IX yang harus dikuasai siswa (Kemdiknas, 2006, p.351).
Extraneous cognitive load disebabkan oleh prosedur maupun teknik penyajian materi yang tidak sesuai dengan kegiatan pembelajaran, contohnya, penggunaan bahan ajar yang membingungkan, cara guru menjelaskan materi matematika terlalu cepat, suara gaduh, dan tampilan media pembelajaran pada komputer yang terlalu banyak animasinya. Teknik penyajian materi yang baik dan tidak menyulitkan pemahaman akan menurunkan extraneous cognitive load, namun, teknik yang buruk dan menyulitkan pemahaman akan meningkatkan muatan kognitif ini (Sweller, 2010b, p.125). Pemahaman materi akan mudah terjadi apabila ada pengetahuan prasyarat yang cukup dan dapat dipanggil dari memori jangka panjang. Jika pengetahuan prasyarat ini dapat hadir dalam memori pekerja secara otomatis maka extraneous cognitive load dapat diminimalkan. Semakin banyak pengetahuan prasyarat yang dapat digunakan semakin minimum muatan kognitif yang muncul.

Germane cognitive load disebabkan oleh banyaknya usaha mental seseorang yang dicurahkan dalam proses belajar. Germane cognitive load memiliki hubungan positif dengan pembelajaran karena berkaitan dengan pembentukan skema dan otomatisasi pengolahan informasi, contohnya, pemberian soal-soal latihan yang sesuai dengan materi yang dipelajari serta penggunaan media geogebra maupun alat peraga geometri. Jika memori pekerja telah dipenuhi oleh intrinsic dan extraneous cognitive load maka tidak ada ruang yang tersisa untuk germane cognitive load, hal ini menyebabkan memori pekerja tidak dapat mengkonstruksi, mengkoding, dan mengintegrasikan materi yang dipelajari. Germane cognitive load antara seorang siswa dengan siswa lain mungkin berbeda karena dipengaruhi oleh latar belakang pengalaman, pengetahuan, serta karakteristik siswa (Sweller, 2010b, p.126).

CLT telah mengembangkan prinsipprinsip mendesain bahan ajar dengan meminimalkan muatan kognitif yang tidak penting, sehingga siswa dapat memfokuskan perhatiannya ketika belajar (Sweller, et al., 2011, p.55). Tiga hal yang perlu diperhatikan dalam menyajikan bahan ajar, yaitu meminimalkan efek intrinsic cognitive load, meminimalkan efek extraneous cognitive load dan memaksimalkan efek germane cognitive load. Dengan teknik penyajian bahan ajar berdasarkan CLT, pemahaman siswa dapat ditingkatkan karena bahan ajar tersebut disusun sesuai dengan kapasitas berfikir siswa. Pengetahuan tentang proses 
kognitif siswa dan faktor-faktor yang meminimalkan muatan kognitif akan membekali guru untuk menjelaskan mengapa metode pembelajaran yang digunakan efektif dan berdampak terhadap prestasi siswa atau tidak (Sweller, 1994, p.296; Sweller, et al., 2011, p.55; Chandler \& Sweller, 1991, p.294).

Aktifitas secara bersamaan dalam memori pekerja untuk menangani sejumlah elemen masalah berpotensi menambah muatan kapasitas memori sehingga dapat menghalangi proses belajar. Dengan kata lain, terjadi peningkatan pada extraneous cognitive load. Untuk mencegah meningkatnya extraneous cognitive load, Sweller beserta rekan-rekannya merancang dan menguji strategi pembelajaran alternatif, salah satunya adalah strategi worked example effect. Strategi ini efektif digunakan untuk mencegah meningkatnya muatan kognitif (Retnowati, 2012, p.394).

Secara umum, worked example merupakan cara memecahkan suatu masalah kemudian dilanjutkan dengan praktek pada sejumlah masalah yang memiliki kesamaan karakteristik. Seorang guru yang menerapkan strategi worked example harus mampu memberikan contoh pemecahan masalah yang dapat diikuti atau ditiru oleh siswa. Pernyataan tentang masalah beserta langkah-langkah menuju solusi akhir dicantumkan dalam worked example (Sweller, et al., 2011, p.99).

Carroll (1994, p.365) mengemukakan bahwa worked example sangat membantu siswa, terutama bagi siswa dengan prestasi rendah, pernah mengalami kegagalan dalam belajar matematika, dan memiliki kesulitan dalam belajar. Carroll juga menyatakan bahwa worked example digunakan untuk mencegah siswa melakukan kesalahan saat belajar menyelesaikan masalah. Strategi ini berfungsi untuk: (1) membimbing siswa dalam kegiatan pemecahan masalah di sekolah; (2) mengingatkan siswa tentang langkah-langkah penyelesaian masalah ketika mereka mengerjakan tugas di rumah; dan (3) membantu siswa belajar khususnya ketika masalah yang harus diselesaikan menjadi semakin rumit (Carroll, 1994, p.365).

Sweller dan Cooper (Sweller, et al., 2011, p.101) menyajikan pasangan antara worked example dengan masalah identik yang harus diselesaikan, selanjutnya keduanya menyatakan bahwa setelah mempelajari suatu masalah beserta pemecahannya, motivasi siswa akan meningkat untuk menyelesaikan masalah yang karakternya sama. Struktur yang sering dipakai pada penyelidikan efek worked example yaitu pasangan antara contoh dan soal (Sweller, et al., 2011, pp.104-105) atau biasa disebut dengan strategi study one-solve one (Retnowati, 2014, p.85). Sweller dan Cooper (Retnowati, 2014, p.88) menyatakan worked example dengan struktur study one solve one merupakan metode yang efektif digunakan terutama ketika siswa mempelajari materi-materi baru.

Atkinson, Derry, Renkl, dan Wortham (2000, p.195) mengemukakan bahwa: (1) agar dapat dipahami, setidaknya perlu disajikan dua pasang contoh dan soal dari setiap masalah yang harus diselesaikan siswa, (2) pembelajaran melalui penyajian satu worked example yang langsung diikuti soal setipe memberikan dampak yang lebih baik pada hasil belajar daripada penyajian seperangkat contoh-contoh dulu baru diikuti kumpulan soal. Sependapat dengan Sweller, et al. (2011, p.105) yang memberikan catatan penting bahwa "...the method of showing students a set of worked examples followed later by a similar set of problems to solve led to the worst learning outcomes."

Strategi worked example dikatakan efektif karena dapat mengurangi extraneous cognitive load (Sweller, et al., 2011, p.108). Namun, penerapan worked example dalam pembelajaran juga tidak lepas dari kritik. Salah satu kritik berkaitan dengan keaktivan siswa ketika belajar. Worked example dinilai tidak sesuai dengan kaidah pembelajaran aktif dan dipandang meminimalkan pengalaman memecahkan masalah. Padahal, pembelajaran aktif tidak hanya berorientasi pada keaktifan siswa secara fisik namun terkait pula dengan keaktivan secara mental yaitu ketika siswa mencurahkan pemikiran dan belajar menggunakan worked example dalam pemecahan masalah (Sweller, et al., 2011, p.107).

Seiring dengan meningkatnya pengetahuan siswa sebuah strategi pembelajaran yang pada awalnya efektif untuk siswa pemula (pengetahuan awalnya lemah) menjadi tidak efektif bagi siswa yang sudah memiliki banyak pengetahuan (Plass, Kalyuga, \& Leutner, 2010, p.68). Seringkali siswa pemula membutuhkan penjelasan detail tentang petunjuk belajar sehingga mereka dapat memperoleh pemahaman tentang materi pembelajaran, tetapi dengan meningkatnya pengetahuan mungkin penjelasan tersebut sudah tidak dibutuhkan. Jika penjelasan detail tetap diberikan pada siswa berpengetahuan baik maka hal ini akan menjadi pemicu meningkatnya cognitive load dan berpotensi 
Pythagoras, 12 (1), 2017 - 37

Fitraning Tyas Puji Pangesti, Endah Retnowati

mengganggu daripada membantu proses pengolahan informasi.

Secara umum terdapat dua efek kognitif yang teridentifikasi sebagai sumber dari extraneous cognitive load dan berpengaruh terhadap keefektifan desain worked example yaitu: split-attention effect dan redundancy effect (Retnowati, 2014, p.94). Split-attention diakibatkan oleh penyajian berbagai sumber informasi secara terpisah (Sweller, et.al, 2011, p.111), seharusnya sumber-sumber tersebut harus diintegrasikan supaya informasi mudah dipahami. Proses mengintegrasikan berbagai sumber informasi melibatkan proses pencarian dan pencocokan serta menemukan hubungan diantara sumber-sumber tersebut. Proses ini akan meningkatkan extraneous cognitive load sehingga mengurangi efektivitas pembelajaran. Sumber-sumber informasi yang disajikan secara terpisah juga memiliki dampak negatif dalam pembelajaran termasuk ketika digunakan pada worked example kecuali bagi siswa dengan pengetahuan awal tinggi knowledge.
Redundansi terjadi apabila beberapa sumber informasi yang bermakna sama disajikan secara simultan (Sweller, et al., 2011, p.141) sehingga menyebabkan terjadinya tumpang tindih informasi. Selain itu, menyajikan kembali informasi yang telah dipahami dengan baik oleh siswa juga menyebabkan redundancy effect (efek pengulangan). Siswa dengan pengetahuan awal rendah diuntungkan oleh proses pembelajaran yang berorientasi pada worked example pada tahap awal akuisisi pengetahuannya. Namun, ketika pengetahuan awal dan keahlian siswa telah meningkat, pembelajaran yang berorientasi pada worked example dapat menjadi redundan dan menyebabkan extraneous cognitive load.

Memperhatikan uraian tersebut, peneliti merasa perlu mengembangkan bahan ajar matematika SMP terutama berisi materi pengayaan geometri. Penyusunan bahan ajar ini menggunakan prinsip-prinsip CLT dalam penyajiannya. Prinsip-prinsip CLT sebagaimana yang dirangkum pada Tabel 1 merupakan menjadi landasan dalam mengembangkan bahan ajar.

Tabel 1. Prinsip-prinsip CLT dalam Bahan Ajar

\begin{tabular}{llll}
\hline \multicolumn{4}{c}{ Prinsip CLT } \\
\hline 1. Mengelola intrinsic cognitive load dalam \\
penyajian materi pengayaan
\end{tabular}

3. Menerapkan strategi worked example pairs sesuai kemampuan awal siswa

4. Ketersediaan masalah dengan pertanyaan terbuka (goal-free problem)

5. Gambar yang digunakan meminimalkan kemungkinan perhatian siswa terpisah (splitattention effect)

6. Meminimalkan kemungkinan tumpang tindih informasi (redundancy effect)

Indikator

1. Mempertimbangkan kompleksitas isi materi pengayaan

2. Mempertimbangkan kompleksitas isi materi dalam penyajian soal pengayaan

3. Terdapat uraian materi prasyarat

4. Materi pengayaan sesuai dengan tingkat kemampuan siswa SMP

1. Ketersediaan kegiatan siswa dalam memperoleh pengetahuan

2. Ketersediaan lembar kerja siswa

3. Memfasilitasi siswa agar mampu berfikir secara kritis

1. Ketersediaan worked example

2. Mempertimbangkan kesesuaian penyusunan contoh dengan kemampuan siswa

3. Kejelasan langkah penyelesaian soal pengayaan yang tersaji dalam contoh

1. Ketersediaan soal pengayaan yang tidak memiliki jawaban tunggal

2. Mempertimbangkan relevansi pertanyaan terbuka dengan materi pengayaan

1. Informasi dalam gambar dapat menjelaskan isi gambar

2. Deskripsi dari gambar membantu siswa memahami isi gambar dengan efektif

3. Mempertimbangkan pewarnaan untuk memperjelas gambar

1. Informasi yang disajikan dalam soal pengayaan tidak berlebihan/bertumpukan

2. Informasi yang sama disajikan sekali
Sesuai dengan permasalahan di atas, maka tujuan penelitian ini adalah (1) menghasilkan bahan ajar geometri SMP berbasis CLT dan mendeskripsikan proses pengembangannya, dan 
Pythagoras, 12 (1), 2017 - 38

Fitraning Tyas Puji Pangesti, Endah Retnowati

(2) mendeskripsikan kualitas bahan ajar tersebut ditinjau dari aspek kevalidan, kepraktisan, dan keefektifan.

Manfaat pelaksanaan penelitian pengembangan ini adalah (1) tersedianya bahan ajar geometri SMP berbasis CLT terutama berisi materi-materi pengayaan yang layak digunakan ditinjau dari aspek kevalidan, kepraktisan, dan keefektifan, serta (2) guru dan siswa dapat menggunakan bahan ajar geometri SMP berbasis CLT yang dikembangkan sebagai sumber belajar matematika yang berkualitas.

\section{METODE}

Penelitian ini berparadigma mixed-method menggunakan embedded design (Creswell, 2012 , p.544). Metode penelitian utamanya adalah kualitatif dengan tujuan untuk mengembangkan produk dalam pembelajaran matematika. Sebagai supporting data dan untuk mempermudah penilaian terhadap model yang dikembangkan digunakan metode penelitian kuantitatif. Produk yang dikembangkan oleh peneliti berupa buku pengayaan geometri SMP berbasis CLT yang tersusun dari dua materi yaitu: pengayaan segitiga dan segi empat, serta pengayaan bangun ruang sisi datar.

Penelitian dilaksanakan pada bulan Maret sampai dengan Mei Tahun Pelajaran 2016/2017 di SMPN 1 Kertek dan SMPN 1 Sapuran yang berada di wilayah Kabupaten Wonosobo Propinsi Jawa Tengah. Pemilihan lokasi ini dikarenakan kemudahan akses yang dimiliki oleh peneliti sebagai guru di sekolah ini.

Agar diperoleh produk pengembangan yang benar-benar memenuhi aspek kevalidan, kepraktisan, dan keefektifan maka peneliti mengujicobakan produk tersebut pada 32 siswa kelas VII H SMPN 1 Kertek dan 32 siswa kelas VIII A SMPN 1 Sapuran beserta masing-masing satu orang guru matematika yang mengajar di kelas tersebut. Dua tingkat kelas ini digunakan untuk pengambilan data penelitian karena semua siswa di kelas tersebut terkategori tuntas setelah mengikuti proses pembelajaran, khususnya pada SK dan KD geometri yang tercantum dalam Kurikulum 2006.

Model pengembangan bahan ajar yang digunakan dalam penelitian diadopsi dari model Plomp (2007, p.15) dengan langkah-langkah sebagai berikut: (1) preliminary research, terdiri atas analisis kebutuhan dan konteks, kajian literatur, serta pengembangan kerangka konseptual dan teoritis penelitian; (2) prototyping phase, yang terdiri atas penyusunan dan pengembangan produk, serta evaluasi formatif 1 dan 2; (3) assessment phase, terdiri atas evaluasi sumatif dan pengajuan rekomendasi pengembangan produk selanjutnya.

Tujuan evaluasi formatif 1 adalah mengukur kevalidan bahan ajar dan instrumen keefektifannya sebelum digunakan di lapangan. Pelaksanaan evaluasi dibantu oleh tiga validator yaitu: dua orang dosen jurusan pendidikan matematika FMIPA UNY dan satu orang dosen pembimbing. Dalam evaluasi ini, peneliti mengujicobakan prototip 1 kemudian menganalisis hasilnya. Jika data yang diperoleh dari lembar validasi bahan ajar menunjukkan bahwa prototip 1 valid maka prototip tersebut dapat digunakan, tetapi jika tidak valid maka prototip perlu direvisi atau diganti. Prototip hasil revisi perlu divalidasi kembali agar diketahui tingkat kevalidannya. Prototip 1 yang telah memenuhi aspek kevalidan dinamakan dengan prototip 2. Demikian pula jika data yang diperoleh dari lembar validasi instrumen penilaian prestasi belajar menunjukkan bahwa keseluruhan instrumen valid maka instrumen dapat digunakan dalam tahap evaluasi sumatif.

Tujuan evaluasi formatif 2 adalah mengukur kepraktisan bahan ajar yang dengan meminta penilaian dari guru dan siswa yang menggunakannya. Evaluasi ini dilaksanakan dalam skala terbatas yaitu pada masing-masing sembilan siswa kelas VII H dan VIII A beserta dua guru pengampu mata pelajaran matematika dalam kelas tersebut. Guru dan siswa diminta membaca dan mempelajari bahan ajar kemudian memberikan catatan di bagian mana dari bahan ajar tersebut yang tidak dipahami. Masukan yang diberikan oleh guru dan siswa merupakan acuan untuk menganalisis dan merevisi prototip 2. Prototip yang telah memenuhi aspek kepraktisan dalam skala terbatas dinamakan dengan prototip 3 .

Evaluasi sumatif dilaksanakan dengan mengujicobakan produk pada subjek coba dalam skala besar yang melibatkan 64 siswa dari kedua kelas. Evaluasi ini bertujuan untuk mengetahui tingkat kepraktisan dan keefektifan bahan ajar yang dikembangkan. Tahap evaluasi sumatif dilakukan dengan cara melaksanakan pembelajaran pengayaan dengan menggunakan prototip 3 oleh guru dari masing-masing sekolah kemudian pada akhir pembelajaran siswa diberikan tes prestasi belajar dan lembar penilaian kepaktisan bahan ajar. Pembelajaran di kelas VII dilakukan dalam enam kali pertemuan sedangkan di kelas VIII dilaksanakan dalam delapan kali pertemu- 
an. Data yang diperoleh dari evaluasi dianalisis oleh peneliti, jika data menunjukkan bahwa prototip 3 telah memenuhi aspek kepraktisan dan keefektifan maka prototip tersebut dinamakan prototip final. Namun, jika belum menunjukkan terpenuhinya kedua aspek tersebut maka harus dilakukan revisi dan diujicobakan kembali sampai diperoleh prototip final.

\section{Instrumen dan Teknik Pengumpulan Data}

Jenis data dalam penelitian ini berupa data kualitatif dan kuantitatif. Data kualitatif berupa saran atau komentar dari validator. Data kuantitatif diperoleh dari skor tanggapan validator terhadap bahan ajar, skor penilaian kepraktisan bahan ajar oleh guru dan siswa, dan hasil penilaian prestasi belajar siswa.

Instrumen yang digunakan untuk mengumpulkan data pada penelitian ini dibedakan dalam 3 kategori, yaitu: (1) instrumen kevalidan, terdiri atas lembar validasi bahan ajar dan lembar validasi instrumen penilaian prestasi belajar; (2) instrumen kepraktisan berupa lembar penilaian kepraktisan bahan ajar oleh guru dan siswa; dan (3) instrumen keefektifan bahan ajar berupa tes prestasi belajar siswa berbentuk pilihan ganda yang terdiri atas 20 butir soal untuk kelas VII dan 25 butir soal untuk kelas VIII.

Penilaian kevalidan ditinjau dari lima komponen yaitu: kelayakan isi, kelayakan kebahasaan, kesesuaian strategi penyusunan bahan ajar berdasarkan CLT, kelayakan penyajian, dan kelayakan kegrafikaan. Skor penilaian terdiri atas lima kriteria yaitu: sangat baik (skor 5), baik (skor 4), cukup baik (skor 3), kurang baik (skor 2), dan tidak baik (skor 1). Secara keseluruhan terdapat 95 butir pernyataan untuk memvalidasi keseluruhan bahan ajar yang dikembangkan.

Kriteria kevalidan dalam lembar validasi instrumen penilaian prestasi belajar ditinjau dari empat komponen yaitu: kesesuaian butir soal dengan indikator, kesesuaian kalimat dengan EYD, ketepatan kunci jawaban, kesesuaian distraktor (pengecoh). Apabila seluruh komponen tersebut telah divalidasi maka akan diperoleh kesimpulan apakah butir-butir soal yang dikembangkan memiliki kriteria: baik, perlu revisi minor, perlu revisi mayor, atau diganti.

Penilaian kepraktisan oleh guru dan siswa masing-masing ditinjau dari empat komponen yaitu: desain buku, penyajian materi, penggunaan buku, dan kesesuaian penyusunan bahan ajar berdasarkan CLT. Terdapat 20 butir pernyataan yang dapat digunakan oleh guru dan siswa untuk mengukur kepraktisan bahan ajar. Skor penilaian kepraktisan terdiri atas lima kriteria yaitu: sangat setuju (skor 5), setuju (skor 4), ragu-ragu (skor 3), tidak setuju (skor 2), dan sangat tidak setuju (skor 1).

Penilaian keefektifan dilaksanakan setelah siswa mengikuti proses pembelajaran. Setiap siswa diberikan soal tes prestasi belajar dan mengerjakan soal secara mandiri. Hasil tes tersebut dinyatakan dalam skala 0-100.

\section{Teknik Analisis Data}

Analisis data dalam penelitian ini bertujuan untuk mengolah data penelitian sehingga mengarah pada simpulan yang mendeskripsikan dan menjawab pertanyaan penelitian. Analisis data dilakukan secara berkelanjutan terutama untuk data yang bersifat kualitatif. Data-data ini umumnya berisi informasi untuk merevisi prototip bahan ajar yang dikembangkan sehingga mencapai kualitas valid, praktis dan efektif. Lebih lanjut pada evaluasi formatif 1 dan 2 serta evaluasi sumatif diperoleh data-data kuantitatif dari lembar validasi bahan ajar, lembar validasi instrumen penilaian, lembar penilaian kepraktisan bahan ajar oleh guru dan siswa, dan hasil tes prestasi belajar siswa.

Sebelum mengetahui valid atau tidaknya keseluruhan bahan ajar yang dikembangkan, terlebih dahulu dilaksanakan analisis terhadap lima komponen kelayakan bahan ajar untuk setiap materi pengayaan, yaitu dengan mengkonversikan hasil penskoran yang diperoleh dari kelayakan isi, kebahasaan, penyajian, kegrafikaan, dan kesesuaian strategi penyusunan bahan ajar berdasarkan CLT. Secara umum, tujuan analisis tersebut adalah untuk mengetahui seberapa baik komponen-komponen yang digunakan oleh peneliti dalam penyusunan bahan ajar sedangkan tujuan utamanya adalah mengukur kesesuaian struktur bahan ajar dengan karakteristik CLT yang telah ditetapkan dalam penelitian ini.

Berdasarkan kepatutan pengklasifikasian hasil penilaian, peneliti menetapkan penilaian bahan ajar dalam lima kriteria. Adapun pedoman pengubahan skor menjadi lima kriteria disajikan dalam Tabel 2.

Tabel 2. Pedoman Penilaian dalam Lima Kriteria

\begin{tabular}{cc}
\hline Interval & Kriteria \\
\hline$\geq 91 \% \mathrm{X}$ & Sangat Baik \\
$78 \% \mathrm{X}-90 \% \mathrm{X}$ & Baik \\
$65 \% \mathrm{X}-77 \% \mathrm{X}$ & Cukup \\
\hline
\end{tabular}


Pythagoras, 12 (1), 2017 - 40

Fitraning Tyas Puji Pangesti, Endah Retnowati

\begin{tabular}{cc}
$51 \% \mathrm{X}-64 \% \mathrm{X}$ & Kurang Baik \\
$\leq 50 \% \mathrm{X}$ & Tidak Baik \\
\hline
\end{tabular}

Keterangan:

$X=$ Skor maksimum

$=\Sigma$ butir kriteria skor tertinggi

Setelah dilaksanakan analisis terhadap lima komponen kelayakan bahan ajar selanjutnya dilakukan analisis kevalidan keseluruhan bahan ajar. Langkah-langkah yang digunakan untuk memberikan kriteria kevalidan bahan ajar yang dikembangkan yaitu: (1) merekap skor dari lembar validasi yang telah diisi oleh setiap validator, (2) hasil yang diperoleh pada tahap (1) kemudian dirujuk pada Tabel 3. Secara keseluruhan terdapat 95 butir pernyataan dalam lembar validasi bahan ajar $(X=475)$, sehingga dapat ditetapkan kriteria kevalidan keseluruhan bahan ajar seperti pada Tabel 3.

Tabel 3. Kriteria Kevalidan Bahan Ajar

\begin{tabular}{cc}
\hline Interval & Kriteria \\
\hline$\geq 432$ & Sangat Baik \\
$371-431$ & Baik \\
$305-370$ & Cukup \\
$239-304$ & Kurang Baik \\
$\leq 238$ & Tidak Baik \\
\hline
\end{tabular}

Bahan ajar dinyatakan memenuhi aspek kevalidan jika penilaian dari setiap validator minimal berada pada kriteria "Baik". Apabila belum mencapai kriteria tersebut maka dilakukan revisi.

Analisis data kevalidan instrumen penilaian prestasi belajar dilakukan dengan langkahlangkah sebagai berikut: (1) mengecek kesimpulan pada lembar validasi instrumen penilaian prestasi belajar yang telah diisi oleh validator, (2) merevisi maupun mengganti butir soal yang belum berada pada kriteria "Baik", (3) Instrumen penilaian prestasi belajar dinyatakan valid apabila seluruh butir soal berada pada kriteria "Baik".

Langkah-langkah yang digunakan untuk memberikan kriteria kepraktisan bahan ajar adalah sebagai berikut: (1) Merekap total skor dari lembar kepraktisan yang telah diisi oleh guru dan siswa, (2) menghitung rata-rata skor dari lembar kepraktisan yang telah diisi oleh guru dan siswa, (3) Hasil yang diperoleh pada poin (2) kemudian dirujuk pada Tabel 4. Lembar penilaian kepraktisan bahan ajar terdiri atas 20 pernyataan sehingga $X=100$, sehingga dapat ditetapkan kriteria kepraktisan bahan ajar, seperi pada Tabel 4.

Bahan ajar dinyatakan memenuhi aspek kepraktisan jika rata-rata penilaian dari guru dan siswa masing-masing minimal berada pada kriteria "Baik".

Tabel 4. Kriteria Kepraktisan Bahan Ajar

\begin{tabular}{cc}
\hline Interval & Kriteria \\
\hline$\geq 91$ & Sangat Baik \\
$78-90$ & Baik \\
$65-77$ & Cukup \\
$51-64$ & Kurang Baik \\
$\leq 50$ & Tidak Baik \\
\hline
\end{tabular}

Analisis data keefektifan dilakukan terhadap hasil tes prestasi belajar yang diperoleh siswa setelah mengikuti pembelajaran menggunakan bahan ajar yang dikembangkan. Langkahlangkah analisis data keefektifan adalah sebagai berikut: (1) menghitung banyaknya jawaban benar yang diperoleh setiap siswa, (2) jawaban benar pada setiap butir soal untuk kelas VII diberi skor 5, sedangkan jawaban benar pada setiap butir soal untuk kelas VIII diberi skor 4 sehingga diperoleh skor maksimal 100 apabila semua soal dijawab benar, dan (3) menilai hasil tes siswa yaitu mengalikan banyaknya jawaban benar dengan bobot skor dari setiap butir soal.

Bahan ajar dikatakan efektif apabila $75 \%$ siswa memperoleh nilai sama atau melebihi Kriteria Ketuntasan Minimal (KKM) pengayaan materi geometri. Adapun KKM pengayaan materi geometri yang ditetapkan yaitu 71,3 dan nilai rata-rata siswa secara klasikal minimal 75 .

\section{HASIL DAN PEMBAHASAN}

Peneliti merancang prototip awal bahan ajar bagi kelas VII pada materi pengayaan segitiga dan segi empat serta bagi kelas VIII pada materi pengayaan bangun ruang sisi datar. Materi-materi tersebut dipilih karena memungkinkan peneliti untuk mengujicobakan bahan ajar yang dikembangkan pada akhir semester dua tahun ajaran 2015/2016.

Kerangka bahan ajar yang dikembangkan tersusun dalam empat bagian yaitu A, B, C, dan D. Bagian A berisi judul bab, kompetensi dasar pengayaan, kosakata baru, peta kompetensi, dan peta urutan materi. Judul bab disesuaikan dengan tema materi pengayaan yang akan dipelajari siswa. Kompetensi dasar pengayaan berisi hal-hal yang harus dicapai siswa setelah mempelajari materi pengayaan. Kosakata baru berisi istilah-istilah baru yang akan dipelajari siswa. Peta kompetensi merupakan garis besar hubungan kompetensi dasar dan kompetensi dasar pengayaan. Peta urutan materi merupakan garis besar hubungan antar materi yang telah dan akan dipelajari. 
Bagian B berisi materi-materi prasyarat yang dibutuhkan siswa untuk mempelajari materi pengayaan. Bagian ini disajikan dalam bentuk tabel ringkasan konsep awal. Bentuk tabel dipilih agar penyusunan materi-materi prasyarat dapat diringkas dan cukup disajikan dalam satu tampilan. Bagian $\mathrm{C}$ merupakan bagian inti materi pengayaan yang berisi judul sub bab, rekreasi matematika, uraian materi, membangun pengetahuan baru, belajar melalui contoh, kunci jawaban, dan daftar pengetahuan baru.

Judul subbab disesuaikan dengan sub materi yang akan diuraikan dalam setiap bab misalnya pada bab pengayaan segitiga dan segi empat terdapat subbab segi banyak, sudut-sudut pada segitiga, dan jumlah ukuran sudut dalam segi banyak. Rekreasi matematika menyajikan keterkaitan maupun manfaat mempelajari materi pengayaan dalam kehidupan sehari-hari. Uraian materi disajikan secara singkat, padat, dan jelas sesuai dengan kompetensi dasar pengayaan yang dipelajari. Membangun pengetahuan baru berisi pertanyaan-pertanyaan terkait dengan uraian materi yang harus dijawab siswa. Daftar pengetahuan baru berupa cek list materi-materi yang telah dipelajari dan dipahami. Belajar melalui contoh merupakan pasangan contoh dan soal yang disajikan untuk melatih kemampuan memahami materi dan kemampuan berhitung. Kunci jawab soal latihan berisi kunci jawab soal-soal dalam belajar melalui contoh.

Bagian D berisi bengkel kreasi dan soalsoal aplikasi untuk mengembangan kemampuan berfikir kreatif siswa. Bengkel kreasi berisi kegiatan dan soal yang memiliki berbagai macam jawaban benar. Kembangkan kemampuanmu berisi soal-soal latihan yang disusun berdasarkan konteks kehidupan sehari-hari. Layout bahan ajar juga menjadi perhatian peneliti saat proses penyusunan bahan ajar dengan tujuan agar tidak ada uraian atau paragraf yang terpisah oleh halaman.

Peneliti menggunakan strategi goal-free dan worked example dalam penyusunan materi pengayaan. Strategi goal-free digunakan pada soal dengan tujuan tidak tunggal. Tujuan penerapan strategi ini yaitu siswa belajar mengaplikasikan solusi yang telah mereka pelajari sehingga pengetahuan tentang struktur masalah beserta cara penyelesaiannya akan meningkat. Dalam penelitian ini, strategi goal-free hanya diterapkan pada bagian D bahan ajar yaitu dalam bengkel kreasi sehingga peneliti tetap mampu menyelesaikan penelitian sesuai waktu yang telah dijadwalkan. Worked example digunakan ketika siswa mempelajari materi yang berkaitan dengan perhitungan, misalnya menentukan keliling dan luas daerah segi lima beraturan.

Strategi worked example yang diterapkan dalam bahan ajar diganti dengan istilah "belajar melalui contoh" agar mudah dipahami oleh siswa. Belajar melalui contoh berisi pasangan contoh dan soal yang setipe atau dikenal dengan study one-solve one. Pada mulanya siswa diinstruksikan untuk mempelajari contoh soal beserta langkah penyelesaiannya secara mandiri, kemudian mereka diminta mengerjakan soal yang telah disediakan. Siswa diminta menyelesaikan soal dengan mengikuti langkah penyelesaian seperti dalam contoh. Beberapa worked example dalam bahan ajar ini disajikan lebih dari satu kali meskipun untuk tipe soal yang sama. Hal ini dimaksudkan agar: (1) siswa memiliki lebih banyak kesempatan untuk belajar memahami langkah-langkah penyelesaian soal, (2) siswa mampu memperdalam pengetahuan dan pengalaman dalam penyelesaian soal, (3) siswa tidak terbebani dengan perubahan tipe soal yang terlalu cepat, dan (4) siswa dapat belajar secara bertahap dan kontinyu.

Worked example yang disajikan oleh peneliti disusun dengan meminimalkan adanya split-attention dan redundancy effect. Splitattention effect diminimalkan dengan: (1) teks soal dan gambar disajikan secara terpadu yaitu keduanya dapat diamati dalam satu arah pandang, (2) gambar yang ditampilkan telah dilengkapi dengan ukuran maupun keterangan pendukung, (3) mempertimbangkan kontras warna yang digunakan dalam gambar. Redundancy effect dapat diminimalkan dengan: (1) menghindari adanya tumpang tindih informasi yaitu teks soal tidak memuat ukuran maupun keterangan pendukung yang telah ditampilkan pada gambar, (2) informasi yang sama hanya disajikan sekali, misalnya pada teks soal dituliskan "Perhatikan gambar berikut. Hitunglah luas permukaan prisma segi lima beraturan tersebut." bukan "Perhatikan gambar prisma segi lima beraturan berikut. Hitunglah luas permukaan prisma segi lima beraturan tersebut."

Setelah produk awal bahan ajar disusun berdasarkan saran dan masukan dari para ahli, produk tersebut diujicobakan dalam evaluasi formatif 1, 2 dan evaluasi sumatif. Tabel 5 adalah bagian-bagian yang divalidasi.

Skor validasi yang diperoleh dari validator 2 dan 3 akan digabungkan sehingga diper- 
oleh penilaian kevalidan bahan ajar dan instrumen penilaian prestasi belajar siswa secara menyeluruh. Berikut ini hasil evaluasi formatif 1 yang ditunjukkan dalam Tabel 6 dan 7 .

Berdasarkan data yang diperoleh dari evaluasi formatif 1 dapat diketahui bahwa penyusunan bahan ajar geometri SMP berbasis CLT telah memenuhi komponen kelayakan isi, kebahasaan, kesesuaian strategi penyusunan bahan ajar berdasarkan CLT, penyajian, dan kegrafikaan. Secara keseluruhan, validator 1 menyatakan bahwa bahan ajar geometri SMP berbasis CLT berada pada kriteria "sangat baik". Demikian pula validator 2 dan validator 3 yang menyatakan bahwa bahan ajar tersebut termasuk dalam kriteria "sangat baik". Mengacu pada dua buah skor tersebut maka dapat disimpulkan bahwa bahan ajar geometri SMP berbasis CLT yang dikembangkan oleh peneliti termasuk dalam kriteria "valid".

Dalam Tabel 7 tampak bahwa validator 1 menyatakan bahwa keseluruhan instrumen penilaian prestasi belajar bagi siswa kelas VII dalam kategori baik dan dapat langsung digunakan pada evaluasi sumatif, namun dalam instrumen penilaian prestasi belajar untuk siswa kelas VIII terdapat lima butir soal yang perlu direvisi terlebih dahulu sebelum diujicobakan. Hasil yang berbeda ditunjukkan oleh validator 2 dan 3 yang menyatakan bahwa terdapat total tujuh butir soal yang masih perlu diperbaiki sebelum instrumen penilaian digunakan di lapangan.

Revisi soal yang dimaksud tidak disebabkan karena kesalahan konsep maupun perhitungan, namun lebih pada pemilihan dan struktur kalimat yang digunakan dalam pendefinisian serta ketidaksesuaian gambar yang disajikan. Ketidaksesuaian penyajian gambar disebabkan karena keterbatasan bentuk gambar dua dimensi untuk memvisualisasikan bentuk benda tiga dimensi. Berdasarkan koreksi dan saran-saran revisi dari validator, peneliti memperbaiki instrumen penilaian prestasi belajar kemudian mengkomunikasikan kembali kepada validator hingga diperoleh instrumen penilaian prestasi belajar bagi siswa kelas VII dan VIII yang valid dan siap digunakan dalam evaluasi sumatif.

Tabel 5. Validator dan Bagian yang Divalidasi

\begin{tabular}{|c|c|c|c|c|c|}
\hline \multirow{2}{*}{ Validator } & \multicolumn{3}{|c|}{ Prototipe Bahan Ajar Pengayaan } & \multicolumn{2}{|c|}{ Instrumen Prestasi Belajar Siswa } \\
\hline & Segitiga dan segi empat & Bangun ruang sisi datar & Cover & Kelas VII & Kelas VIII \\
\hline 1 & $\sqrt{ }$ & $\sqrt{ }$ & $\sqrt{ }$ & $\sqrt{ }$ & $\sqrt{ }$ \\
\hline 2 & - & $\sqrt{ }$ & - & - & $\sqrt{ }$ \\
\hline 3 & $\sqrt{ }$ & - & $\sqrt{ }$ & $\sqrt{ }$ & - \\
\hline
\end{tabular}

Tabel 6. Hasil Validasi Bahan Ajar

\begin{tabular}{|c|c|c|c|c|c|}
\hline \multirow{2}{*}{ Materi } & \multirow{2}{*}{ Komponen Kelayakan } & \multicolumn{3}{|c|}{ Hasil Validasi } & \multirow{2}{*}{ Kesimpulan } \\
\hline & & V 1 & V 2 & V 3 & \\
\hline \multirow{5}{*}{ Pengayaan Segitiga dan Segi Empat } & Isi & 67 & & 68 & sangat baik \\
\hline & Kebahasaan & 23 & & 24 & sangat baik \\
\hline & Kesesuaian CLT & 81 & & 84 & sangat baik \\
\hline & Penyajian & 9 & & 10 & sangat baik \\
\hline & Kegrafikaan & 25 & & 25 & sangat baik \\
\hline \multirow[t]{5}{*}{ Pengayaan Bangun Ruang Sisi Datar } & Isi & 61 & 64 & & baik \\
\hline & Kebahasaan & 23 & 19 & & baik \\
\hline & Kesesuaian CLT & 76 & 81 & & sangat baik \\
\hline & Penyajian & 9 & 9 & & sangat baik \\
\hline & Kegrafikaan & 23 & 25 & & sangat baik \\
\hline \multicolumn{2}{|c|}{ Sampul dan Pendukung Penyajian } & 42 & - & 44 & \\
\hline \multicolumn{2}{|c|}{ Jumlah Skor } & 439 & \multicolumn{2}{|c|}{453} & sangat baik \\
\hline
\end{tabular}

Tabel 7. Hasil Validasi Instrumen Penilaian Prestasi Belajar

\begin{tabular}{lcccccc}
\hline \multirow{2}{*}{ Soal } & \multicolumn{5}{c}{ Hasil Validasi } \\
\cline { 2 - 7 } & Baik & Validator 1 & Validator 2 & \multicolumn{2}{c}{ Validator 3 } \\
\hline Kelas VII & 20 & 0 & Baik & Revisi minor & Baik & Revisi minor \\
Kelas VIII & 20 & 5 & 21 & - & 17 & 3 \\
\hline
\end{tabular}


Pythagoras, 12 (1), 2017 - 43

Fitraning Tyas Puji Pangesti, Endah Retnowati

Tabel 8. Hasil Kepraktisan Bahan Ajar dalam Skala Terbatas

\begin{tabular}{|c|c|c|c|c|c|c|}
\hline & \multicolumn{4}{|c|}{ Hasil Penilaian Kepraktisan } & \multirow{2}{*}{\multicolumn{2}{|c|}{ Kesimpulan }} \\
\hline & \multicolumn{2}{|c|}{ Kelas VII } & \multicolumn{2}{|c|}{ Kelas VIII } & & \\
\hline & Guru & Siswa & Guru & Siswa & Guru & Siswa \\
\hline Jumlah Skor & 84 & 816 & 93 & 801 & & \\
\hline Rata-rata & 84 & 91 & 93 & 89 & & \\
\hline Kriteria & baik & sangat baik & sangat baik & baik & praktis & praktis \\
\hline \multicolumn{7}{|c|}{ Tabel 9. Hasil Kepraktisan Bahan Ajar dalam Skala Luas } \\
\hline & & \multicolumn{5}{|c|}{ Hasil Penilaian Kepraktisan } \\
\hline & & \multicolumn{2}{|c|}{ Siswa Kelas VII } & \multicolumn{3}{|c|}{ Siswa Kelas VIII } \\
\hline Jumlah Skor & & \multicolumn{2}{|c|}{2727} & \multicolumn{3}{|c|}{2756} \\
\hline Rata-rata & & \multicolumn{2}{|c|}{85} & \multirow{2}{*}{\multicolumn{3}{|c|}{$\begin{array}{c}86 \\
\text { baik }\end{array}$}} \\
\hline Kriteria & & \multicolumn{2}{|c|}{ baik } & & & \\
\hline
\end{tabular}

Tabel 10. Hasil Penilaian Keefektifan Bahan Ajar

\begin{tabular}{lcc}
\hline & \multicolumn{2}{c}{ Hasil Penilaian Keefektifan } \\
\cline { 2 - 3 } & Siswa Kelas VII & Siswa Kelas VIII \\
\hline Banyaknya siswa dengan nilai di atas KKM pengayaan & 25 & 24 \\
Persentase siswa dengan nilai di atas KKM pengayaan & $78 \%$ & $75 \%$ \\
Rata-rata Klasikal & 78 & 80 \\
Kriteria Keefektifan & Efektif & Efektif \\
\hline
\end{tabular}

Tabel 11. Contoh Revisi Prototip 1 menjadi Prototip 2

\begin{tabular}{|c|c|c|}
\hline HIm & Penyajian dalam Prototip 1 & $\begin{array}{r}\text { Penyajian dalam Prototip } 2 \\
\end{array}$ \\
\hline 4 & $\begin{array}{l}\text { Sepasang sudut luar berseberangan, besar } \\
\text { sudutnya sama. }\end{array}$ & $\begin{array}{l}\text { Jika dua buah garis sejajar dipotong oleh sebuah garis } \\
\text { lain maka pasangan sudut luar berseberangan yang } \\
\text { terbentuk ukuran yang sama. }\end{array}$ \\
\hline 5 & $\begin{array}{l}\text { Sepasang sudut dalam sepihak, besar } \\
\text { sudutnya berjumlah } 180^{\circ} .\end{array}$ & $\begin{array}{l}\text { Jika dua buah garis sejajar dipotong oleh sebuah garis } \\
\text { lain maka pasangan sudut dalam sepihak yang terbentuk } \\
\text { saling berpelurus. }\end{array}$ \\
\hline 6 & Tampilan gambar segi banyak & Gambar diubah. \\
\hline 7 & $\begin{array}{l}\text { Segi banyak (polygons) adalah bangun } \\
\text { datar tertutup yang terbentuk oleh tiga buah } \\
\text { ruas garis atau lebih. }\end{array}$ & $\begin{array}{l}\text { Segi banyak (polygons) adalah kurva tertutup sederhana } \\
\text { yang dibentuk oleh tiga buah ruas garis atau lebih. }\end{array}$ \\
\hline 44 & $\begin{array}{l}\text { Suatu bangun ruang disebut bidang banyak } \\
\text { (polyhedron) apabila bangun ruang tersebut } \\
\text { dibatasi oleh bidang-bidang datar. }\end{array}$ & $\begin{array}{l}\text { Bidang banyak (polyhedron) adalah bangun ruang yang } \\
\text { semua sisinya berupa daerah segi banyak (polygon). }\end{array}$ \\
\hline 58 & $\begin{array}{l}\text { Belajar melalui contoh } \\
\text { 1. Hitunglah luas permukaan prisma } \\
\text { condong segi enam beraturan berikut. }\end{array}$ & $\begin{array}{l}\text { Soal diubah menjadi } \\
\text { 1. Hitunglah luas permukaan prisma condong segi enam } \\
\text { beraturan berikut, jika diketahui tinggi sepasang- } \\
\text { sepasang jajargenjang pada sisi tegak prisma adalah } \\
12,8 \mathrm{~cm} \text { dan } 12,6 \mathrm{~cm} \text {. }\end{array}$ \\
\hline
\end{tabular}

Evaluasi formatif 2 dilaksanakan setelah guru dan siswa menggunakan prototip bahan ajar yang telah dibagikan di awal pembelajaran. Pelaksanaan evaluasi dibantu oleh dua guru matematika yaitu Bapak Awal Agus Pudjijanto, S.Pd yang mengampu kelas VII H di SMPN 1 Kertek dan Bapak Prasetya S.Pd yang meng- ampu kelas VIII A di SMPN 1 Sapuran. Selain guru, tahap evaluasi ini juga dilaksanakan oleh 18 siswa dari kelas VII H dan VIII A. Siswasiswa ini dipilih secara acak oleh peneliti karena setiap siswa dari kedua kelas tersebut telah menguasai KD-KD geometri prasyarat dan dinyatakan tuntas KKM matematika. Guru dan 
siswa diminta untuk mengisi lembar penilaian kepraktisan bahan ajar dan memberi masukan berupa komentar atau saran yang dapat digunakan oleh peneliti untuk memperbaiki penyusunan bahan ajar. Hasil penilaian kepraktisan untuk materi pengayaan segitiga dan segi empat Tabel 8.

Guru matematika kelas VII $\mathrm{H}$ dan VIII A menyatakan bahwa bahan ajar yang dikembangkan termasuk dalam kriteria baik, sedangkan guru matematika kelas VIII A menyatakan bahwa bahan ajar tersebut berada pada kriteria sangat baik. Hasil tersebut menunjukkan bahwa, menurut guru, bahan ajar yang dikembangkan termasuk dalam kriteria sangat praktis. Pada tahap evaluasi formatif 2 ini didapatkan pula data kepraktisan dari siswa yang menyatakan bahwa bahan ajar dalam kriteria praktis. Data kepraktisan ini disebut sebagai data awal karena nantinya bahan ajar akan dinilai lagi oleh 64 siswa dari kedua kelas tersebut pada saat evaluasi sumatif.

Evaluasi sumatif dilaksanakan di akhir pembelajaran yang melibatkan masing-masing 32 siswa kelas VII dan VIII dari SMPN 1 Kertek dan SMPN 1 Sapuran. Dalam pelaksanaannya didahului dengan pemberian seperangkat soal tes prestasi belajar untuk mengukur keefektifan bahan ajar dan pada pertemuan selanjutnya siswa diminta untuk mengisi lembar penilaian kepraktisan bahan ajar. Soal tes yang digunakan adalah soal-soal yang terdapat dalam instrumen penilaian prestasi belajar dan telah divalidasi dalam tahap evaluasi formatif 1 . Tabel 9 dan 10 berikut menampilkan hasil evaluasi sumatif bahan ajar geometri SMP berbasis CLT.

Setelah dilaksanakan evaluasi sumatif diperoleh data yang menunjukkan bahwa bahan ajar geometri SMP berbasis CLT termasuk dalam kriteria praktis.

Berdasarkan hasil tes prestasi belajar siswa dapat diketahui bahwa keseluruhan bahan ajar geometri SMP berbasis CLT termasuk dalam kriteria efektif. Keefektifan bahan ajar geometri SMP berbasis CLT ini tidak lepas dari proses pembelajaran pengayaan yang dilaksanakan oleh guru di kelasnya. Beberapa catatan penting yang diperoleh peneliti selama mendampingi guru dalam kegiatan pembelajaran di kelas VII A maupun VIII A yaitu: (1) setiap siswa mendapatkan buku pengayaan geometri berbasis CLT sehingga kegiatan berpikir siswa dapat terpantau dengan baik dalam gagasan dan jawaban tertulisnya, (2) guru dan siswa memanfaatkan alat peraga berupa segi banyak, segi lima beraturan, segi enam beraturan, paralelepipedum, dan prisma condong yang telah dipersiapkan oleh peneliti, dan (3) siswa lebih menyukai soal-soal geometri yang memuat gambar.

Tercapainya kriteria kevalidan, kepraktisan, dan keefektifan bahan ajar dipengaruhi oleh adanya kegiatan revisi produk yang telah dilaksanakan oleh peneliti. Revisi ini dibagi dalam dua bagian yaitu: yaitu revisi dari prototip 1 menjadi prototip 2 dan revisi dari prototip 2 menjadi prototip 3. Pada bagian ini akan ditunjukkan pula hasil revisi instrumen penilaian prestasi belajar siswa. Revisi disajikan dalam bentuk tabel agar lebih mudah diamati perubahannya.

Selanjutnya, proses revisi prototip 2 menjadi prototip 3 dilaksanakan berdasarkan masukan yang berasal dari siswa pada tahap evaluasi formatif 2. Dalam pelaksanaannya, peneliti melengkapi dan mendesain ulang sampul bahan ajar geometri SMP berbasis CLT. Desain baru sampul dilengkapi dengan berbagai macam gambar yang dapat menunjukkan isi materi pengayaan.

\section{SIMPULAN}

Berdasarkan hasil penelitian dan pembahasan dapat diperoleh simpulan sebagai berikut: (1) prinsip-prinsip Cognitive Load Theory dalam bahan ajar geometri SMP yang telah dikembangkan tampak dari: (a) penggunaan worked example dalam penyajian contoh dan soal, (b) menghindari penyajian gambar yang menyebabkan perhatian siswa terpisah (splitattention effect), (c) menghindari adanya tumpang tindih informasi (redundancy effect), (d) memperhatikan penyusunan halaman dalam bahan ajar sehingga tidak ada uraian materi maupun pasangan contoh dan soal yang terpisah oleh halaman, dan (e) penerapan expertise reversal effect dengan pemberian soal-soal yang menantang setelah siswa mempunyai prior knowledge yang tinggi melalui pembelajaran dengan worked example, dan (2) berdasarkan hasil evaluasi formatif 1 , formatif 2 , dan sumatif dapat diketahui bahwa tingkat kualitas bahan ajar geometri SMP berbasis Cognitive Load Theory yang dikembangkan termasuk dalam kriteria: (a) valid, (b) praktis, dan (c) efektif. Bahan ajar yang dikembangkan sebaiknya digunakan berbantuan alat peraga bangun ruang yang sesuai dengan materi yang sedang dipelajari. 


\section{DAFTAR PUSTAKA}

Atkinson, R. K., Derry, S. J., Renkl, A., \& Wortham, D. (2000). Learning from examples: Instructional principles from the worked examples research. Educational Research, 70(2), 181-214. doi: 10.3102/00346543070002181.

Bastiani, M. I., \& Rudhito, M. A. (2012). Pemanfaatan program cabri 3D untuk membantu pembelajaran matematika pada pokok bahasan menentukan besar sudut antara dua garis dalam ruang dimensi tiga di kelas X semester II. Penelitian, Pendidikan dan Penerapan MIPA FMIPA $U N Y$ (pp. M101-108). Yogyakarta: UNY.

Carroll, W. M. (1994). Using worked examples as an instructional support in the algebra classroom. Educational Psychology, 360367.

Chandler, P., \& Sweller, J. (1991). Conitive load theory and the format of instruction. Cognition and Instruction, 293-332.

Creswell, J. W. (2012). Educational research: Planning, conducting, and evaluating quantitative and qualitative research. Boston, MA: Pearson Education.

Direktorat Pembinaan SMA. (2008a). Panduan pengembangan bahan ajar. Depdiknas.

Direktorat Pembinaan SMA. (2008b). Panduan penyelenggaraan pembelajaran pengayaan. Depdiknas.

Groth, R. E. (2013). Teaching mathematics in grade 6-12. Los Angeles, CA: SAGE Publications.

NCTM. (2007). From 1980s: What should not be in the algebra and geometry curricula of average college-bound students? Mathematics Teacher, 100, 72-74.

Nieveen, N. (1999). Prototyping to reach product quality. In J. v. Akker, R. M. Branch, K. Gustafson, N. Nieveen, \& T. Plomp, Design approaches and tools in education and training (pp. 125-129). New York, NY: Springer.

Nwike, M. C., \& Cathrine, O. (2013). Effects of use of instructional materials on students cognitive achievement in agricultural science. Journal of Educational and Social Research, 3(5), 103-107 doi: 10.5901/jesr.2013.v3n5p103.

Oladejo, M. A., Olosunde, G. R., Ojebisi, A. O., \& Isola, O. M. (2011). Instructional materials and students' academic achievement in physics: Some policy implications. European Journal of Humanities and Social Science. 2(1), $113-$ 122.

Plass, J. L., Kalyuga, S., \& Leutner, D. (2010). Individual differences and cognitive load theory. In J. L. Plass, R. Moreno, \& R. Brunken, Cognitive load theory (pp. 6587). Cambridge: Cambridge University Press.

Plomp, T. (2007). Educational design Research: An introduction. In J. v. Akker, B. Bannan, A. E. Kelly, N. Nieveen, \& T. Plomp, An introduction to educational design research (pp. 9-36). Enschende: SLO.

Retnowati, E. (2008). Keterbatasan memori dan implikasinya dalam mendesain metode pembelajaran matematika. Seminar Nasional Matematika dan Pendidikan Matematika. Yogyakarta: UNY.

Retnowati, E. (2012). Worked examples in mathematics. 2nd International STEM in Education Conference (pp. 393-395). Beijing: Beijing Normal University.

Retnowati, E. (2014). Psychology of mathematics learning: Constructing knowledge. Yogyakarta: UNY.

Safrina, K., Ikhsan, M., \& Ahmad, A. (2014). Peningkatan kemampuan pemecahan masalah geometri melalui pembelajaran kooperatif berbasis teori van hiele. Jurnal Didaktik Matematika, 1(1), 9-20.

Sarjiman, P. (2006). Peningkatan pemahaman rumus geometri melalui pendekatan realistik di sekolah dasar. Cakrawala Pendidikan, 25(1), 73-92. Diambil dari http://journal.uny.ac.id/index.php/cp/issue /view/91.

Sitepu, B. (2014). Pemanfaatan teknologi informasi dan komunikasi untuk meningkatkan kemampuan menulis naskah buku. Jurnal Pendidikan Penabur, (23), 43-54.

Sweller, J. (1988). Cognitive load during problem solving: Effects on learning. Cognitive Science, 12, 257-285.

Sweller, J. (1994). Cognitive load theory, learning difficulty, and instructional design. Learning and Instruction, 4, 295312. 
Sweller, J. (2009). Cognitive bases of human creativity. Educational Psychology, 1119. doi: 10.1007/s10648-008-9091-6.

Sweller, J. (2010a). Cognitive load theory: Recent theoretical advances. In J. L. Plass, R. Moreno, \& R. Brunken, Cognitive load theory (pp. 29-47). Cambridge: Cambridge University Press.

Sweller, J. (2010b). Element interactivity and intrinsic, extraneous, and germane cognitive load. Educational Psychology, 123-138. doi: 10.1007/s10648-010-91285.

Sweller, J., Ayres, P., \& Kalyuga, S. (2011). Cognitive load theory. New York. NY: Springer.

Wahyuni, A. T., \& Rudhito, M. A. (2012). Efektivitas pembelajaran dengan program CABRI 3D dibanding pembelajaran konvensional pada topik jarak garis dengan bidang. Prosiding Seminar Nasional Penelitian, Pendidikan dan Penerapan MIPA FMIPA UNY (pp. M1M6). Yogyakarta: UNY.

Widoyoko, E. P. (2011). Evaluasi program pembelajaran. Yogyakarta: Pustaka Pelajar.

Wijaya, A., VandenHeuvel-Panhuizen, M., \& Doorman, M. (2015). Opportunity to learn context based tasks provided by mathematics textbooks. Educational Studies in Mathematics, 89, 41-65. doi: 10.1007/s10649-015-9595-1.

Yohanes, B., Subanji, \& Sisworo. (2016). Beban kognitif dalam pembelajaran materi geometri. Jurnal Pendidikan: Teori, Penelitian, dan Pengembangan, 1(2), 187-195. Diambil dari http://jounal.um.ac.id/index.php/jptpp/index. 